\title{
Standard Quality Banking Services of Islamic Banks
}

\author{
Haneen A. Al-Khawaja \\ Faculty of Finance \& Admin. Science, Al-Madinah International University, Malaysia
}

Barjoyai Bardai

Faculty of Finance \& Admin. Science, Al-Madinah International University, Malaysia

\author{
Received: Jan. 2, 2018 Accepted: Mar. 22, 2018 Online published: Mar. 27, 2018 \\ doi:10.5296/jpag.v8i1.12391ＵRL: https://doi.org/10.5296/jpag.v8i1.12391
}

\begin{abstract}
This research discusses in detail the theoretical aspect of the quality standards of banking services of traditional Islamic banks. The criterion of "Shari'ah Compliance" was added by the researcher to the importance and role of dealing with Islamic banks, the definition of this standard and its importance, how to test it for banks as well as how, without the legitimate commitment of these banks to what is classified as Islamic from the foundation, we focus on the importance of the existence of a legal commitment to any Islamic bank to achieve the quality of Islamic banking services of high quality in accordance with Islamic law and laws to achieve a high confidence in the customers who belong to him and deal with his Conspiracy.
\end{abstract}

Keywords: quality banking services, standards quality of banking services, Islamic commitment, SERVQUAL

\section{Introduction}

The last quarter of the twentieth century witnessed a major qualitative development in the banking systems, including the development of Islamic banking services. This development led to the achievement of most of the banking services offered maturity and to the similar services offered by various banking systems. (Gronroos, 1995)

This has led to the reduction of competition between banks on the types of services provided. Hence, the concept of quality banking service emerged as one of the most important areas in which banks can compete with each other. This means that the customers of banks are required to request banking services, not only because of the marketing content they receive from the service, but because of the contents of symbolic values sought by the client and to constitute a better quality for him from his point of view, and within this context, emerged 
concepts such as customer service, customer empathy, speed of delivery, confidentiality banking in, dealing with the method of service delivery, etc., as areas of excellence in the old banking services which is an understanding of the quality of banking services. (Al-Taleb, 2003)

The banking sector represents the most important financial and economic sectors locally and internationally. It represents the economic lifeline of each country. This Islamic sector plays the role of financial intermediation between savers and investors. It also provides various financial and banking services of various types and modern forms. The service industries, including the financial services industry, play an important and distinctive role in the local and international financial markets and economies. Therefore, measuring the quality of banking services presented is one of the most important problems facing the executive management of the bank at present and through which to make the quality of banking services understandable, especially the direction of the financial markets and economic globalization in all its forms. This most especially applies to the financial ones, so that banks are able to provide the highest level of banking services to customers in the global markets. In addition, strong competition in the banking sector (Islamic - commercial) has forced many banks to start programs and levels of quality banking services to study the expectations and quality, where a number of studies and researches have been conducted to prove this. The most important of these is the so-called gap model in measuring the quality of service and the application as well as the testing of results in banking such as credit cards and retail services in Financial and Banking Markets. (Mohammad, 2014)

\section{Services}

The lack of a clear and accurate definition of services when compared to material goods is one of the most obvious obstacles facing service organizations in drawing up their marketing strategies in the services sector effectively. But this does not negate the fact that there have been many attempts to define a clear and precise definition of service that has contributed to the crystallization of dozens of research and studies by academics and practitioners. It has been defined by the American Marketing Association as the activities or benefits offered for sale that are subject to a commodity. (Al-Damour, 2002)

It is also defined as actions, activities or performances provided by one party to another. These activities are considered intangible and do not entail the transfer of ownership of anything, and the provision of the service may be linked or unrelated to a tangible physical product. (Haddad, 1999)

Also, they are defined as any intangible performance which is provided from one party to another without that result in the ownership of something. (Kotler., 1975)

The service in general is an activity or work that the beneficiary or the customer (individual institution - state) receives through the individuals or machines through which the concept of banking service is broader and more comprehensive. (Mohammad, 2014) 


\subsection{Service Features}

Its characteristics are agreed upon by most researchers in the following:

1) Non-tangible (intangible),

2) Climbing or cohesion (service association with its provider),

3) Contrast or heterogeneity,

4) Lack of storage capacity,

5) Demand fluctuation. (Al musaed, 1999)

\section{Quality}

Quality is a requirement for all organizations, both public and private. They are a key factor in the success of organizations because of their role in exploiting resources and achieving a competitive position in the market. Competition for quality of services, to ensure that customer needs are met, is difficult due to the characteristics that make the process of setting clear standards and standards for the quality of services more difficult, compared to achieving a constant level of quality in the field of goods and consumer goods as a result of the ease of developing a fixed working formula, directing the performance of the product in a specific direction and then manufacture this product in a consistent form which ensures high quality.

Researchers look at the quality of services from both internal and external perspectives, which, if properly used together, will enable the organization to identify competitive opportunities. The internal view is based on adhering to the specifications on which the service is designed, the quality of service perceived by the client and to reflect the internal view of the position of management while the external view is based on the attitude of customers and attitudes towards the services provided.

In applying the concept of modern banking marketing, we tend to adopt the second view that the concept of quality of banking service lies in the perception of customers, since this view is based on the idea of the relative quality of the tangible customer and measures the quality as it represents the ability of the institution, to meet the needs of customer service and satisfy them better than competitors. Banking services are not different in terms of procedural nature from one bank to another and may eliminate the typical capabilities of excellence in the service, which is a requirement of competition, and from this concept, highlight's the concept of quality of service as a field of comparative excellence, the context of concepts such as customer service, speed of completion of service, privacy, confidentiality, and the manner in which the service performed by, etc., as areas of excellence in the provision of banking services. (Darwish, 2016)

It is defined as a benchmark to match the actual performance of the service with customer expectations for the service or the difference between the customer's expectations of the service and their perception of the actual performance.

It is also known as the degree of proficiency aimed at satisfying customers' needs. (Imam, 2003) 
Quality is not only a mental concept, but it is also emotional, and it is used to improve performance which means: more satisfied customers, more satisfied employees, greater sales and profits and greater market share.

\section{Quality Services}

The quality of services provided to customers is at the forefront of service organizations that strive to succeed and continue, and in order to achieve outstanding performance, the organization needs to give greater attention to both employees and customers.

Therefore, the quality of services plays an important role in the design and marketing of the service product, which is of great importance to both providers and beneficiaries. The service organizations have become increasingly aware of the importance and role of applying the concept of total quality in achieving their competitive advantages.

The quality of service is defined as excellence in providing the required services effectively so that it should be free of errors, defects and impurities, and offer the lowest possible cost achieved by the complete satisfaction of customers today and in the future through continuous improvement and development, compliance with the requirements and standards of performance and the performance of the work correctly since the first time. (Http://www.ipa.edu.sa)

Also, it is defined as the characteristics that the particular products and service has featured. Hence, the quality is a relative matter based on pre-defined criteria.

The Japanese architect (Takeuchi) believes that the quality of service is an expression of the amount of loss that could have been avoided and that as a product, it may be caused to the community after his extradition as well as include the failure to meet customer expectations, the failure to meet the performance characteristics and the side effect caused by the community such as pollution, noise and other. (Al-Azzawi, 2001)

\section{Quality Banking Services}

It is the comparison between the expectations and the perceptions of the actual performance provided to clients. This entails the existence of a culture for services provided by the bank, that is different from what the bank should offer in order to maintain trust, reputation and safety.

Quality of service is one of the essentials that precedes customer satisfaction. Customer satisfaction, on the other hand, affects the customer's future purchasing decision and understanding (Cronin \& Taylor, 1992). The quality of banking service is also a prerequisite for customer satisfaction and retention. (Howcroft, 1991) (Cronin \& Taylor, 1992) (Taylor \& Baker, 1994)

\section{Measuring the Quality of Banking Services}

Measuring the quality of services is one of the key stages of improvement and development of quality in service organizations, but we find that there is variation in determining how they are measuring the quality of services and the factors as well as the associated changes in the 
business banking fields.

The service is formed in the light of the expectations of the customers. Therefore, the measurement of the quality of banking services must be based on the creation of standards that are related to customer perceptions and express them, ie, the concept of Islamic banking service quality is different from the concept of service in general as defined by the standards. There is a difference between perceived quality by customers and standard quality. (Primio, 1997)

\subsection{Quality Levels of Banking Services}

Quality levels of services provided, where you can look at the factors that have contributed to the increased attention to the quality levels of Islamic banking and divided it into five levels, can be identified: -

- The expected quality: Constitutes quality level which client expects to get from the bank that he deals with it.

- Percipient quality: What is perceived by the bank management to the quality of service provided to satisfy the customer desires a high level

- Technical quality: Represents the way it does banking service by the bank's employees, which are subject to quality specifications.

- The actual quality: The compatibility and the ability to perform the service by using the methods of service well satisfy customers

- The desired quality: Reflects the extent of satisfaction and acceptance received by the bank from its customers when they receive the services provided.

Here are some scientific theories that have emerged to measure the quality of banking services, which are based on two main inputs:

\subsubsection{Introduction Directional}

This approach is based on the fact that the quality of service is a "consensual but not synonymous" concept and is related to the customer's perception of the actual performance of the service provided. Although researchers implicitly recognize "the importance of customer understanding of Quality of service", service and customer satisfaction is a different concept. The common explanation for this difference is that the quality of service as valued and perceived by customers is a form of direction that depends on a long-term cumulative assessment process whereas satisfaction is a fleeting and ephemeral state of mind. The results of a number of studies confirmed that the efficiency of using the actual performance of the service perceived by customers is a measure of the quality of service.

\subsubsection{Introduction to Gap Theory}

This approach is based on the fact that the difference between customers' expectations about the service and actual awareness of the service determines the quality of the service. Therefore, the quality of service is determined by the difference between the expected service 
and the perceived service. A comprehensive study has shown that perceived quality of service is moving from quality to acceptable quality. Accordingly, the quality of service is measured as follows:

1. If the expected quality is greater than the perceived service (actual performance), the quality of service is less than satisfactory.

2. If the expected quality is equal to the perceived quality of service, it is satisfactory.

3. If the expected quality is lower than the perceived quality, the quality of the service is more than satisfactory and oriented towards the ideal quality over the specified term.

In conclusion, I call on the workers in this field to activate the role of the clients by questioning his opinion on the quality of services provided and suggestions on the development to the level that meets the needs and desires of both the customers and financial institution.

\subsection{Quality Standards of Banking Services}

During the past two decades, many researchers have made an investigation about service quality and its importance to the differentiation of the service as well as for gaining competitive advantage that has been recognized (Zeithaml, Berry, \& Parasuraman, 1996) (Ennew, Reed, \& Binks, 1993) "Early scholarly writing on service quality suggested that service quality stems from a comparison of what customers feel a company should offer (their expectations) with the company's actual service performance" (Zeithaml, Parasuraman, \& Malhotra, 2000)

SERVQUAL is an instrument for measuring how customers perceive the quality of a service (Grönroos, 2000). In the mid-1980s Berry and his colleagues Parasuraman and Zeithaml began to investigate what determines service quality and how it is evaluated by customers (Grönroos, 2000). As a result of their study they developed the SERVQUAL instrument for measuring service quality, which initially included 10 service quality dimensions, which were later reduced to the following five: tangibles, reliability, responsiveness, assurance and empathy, as the following:

- Tangibility

It refers to the appearance of the physical facilities available to the service organization, equipment and appearance of individuals, dealers with providers of services and tools and means of communication with them. In many cases, the service may be evaluated by the client based on morphological characteristics or basic escort service; such as physical facilities, machines and equipment.

\section{- Reliability}

It refers to the ability of the organization (service providers) to perform a service that is promised to be reliable and also has a high degree of health and accuracy. The customer is expected to provide accurate service in terms of time, commitment and performance, just as promised. 
- Respond

It relates to the extent of the ability and willingness of service providers to be permanently in customer service and their ability to perform their service when they need them.

- Security

It is used as an indicator to express the degree of feelings of safety and confidence in the service provided and the individual who provides.

- Empathy

It means the degree of customer care and care in particular, attention to its problems and the desire to provide the service according to his needs and desires. This aspect refers to the friendliness and moral understanding as well as dealing between the service provider and the customer.

\subsection{Challenges Facing the Quality of Banking Services}

(Mohammad, 2014). states that quality banking services are difficult to measure by its very nature, where a lot of studies have approved that clients with significant expectations must be compared with the realization of performance for the overall measurement of the quality of banking services and this measure is heavily influenced by means of service approvals, especially global ones, where it requires a shared responsibility between banks departments and divisions, participation by customers in order to adjust these approvals to meet all of the (needs - expectations - ambitions) desired by customers in all parts and in spite of the large number of studies on the quality of services and standards as a model for the gap. For example, development and modernization have addressed it, but it was criticized in terms of difference and contrast between the direction of the banks to be free to trade in financial services, integration and globalization, inclusiveness and due to a variety of reasons:

1. The quality of banking services is difficult to assess by customers opposed to other services, especially in the banking environment, which includes many of the challenges and problems interlocking.

2. Quality of banking services is defined as a comparison between expectations and realization that the actual performance provided to customers requires the existence of a culture of services provided by the bank for what should be provided in order to the availability of reliability, reputation and safety.

3. The process of quality banking services evaluated require a range of dimensions of the most important facilities and techniques used by the bank and human resources as well as the method to determine the banking trends, the means used for customer service, the structure of the bank, local and global relationships and all roads leading to earn and achieve customer satisfaction.

\subsection{Reasons for Establishing a Quality Banking Service}

Reasons for establishing a quality banking service is the attention to the design of the management for the quality of banking services in financial institutions has become very 
necessary. Islamic banks remain far from the developments in the world in the field of quality of communication and information, but has tried to adapt to developments, especially as customers are looking for a precise and personal response to their requirements of various banking products and services in any way and at any time and in return for these transformations, the quality management of banking services must be upgraded to become more creative and interactive with a quick reaction to bring customers with all advanced technological means to achieve alignment between the objectives of the bank. On the other hand, an Islamic response to customers' demands in a permanent and effective way within the overall strategy of the Bank according to a variety of reasons, include : The development of the global and Islamic financial industry, the establishment of clear objectives for the investigation of services locally and globally, raising awareness, banking culture among customers of banks, whether Islamic or commercial, regulating the structure of administrative levels, defining responsibilities and roles to serve customers clearly, opening up, liberalization of local and international banking as well as financial markets, improving research quality of banking marketing and moving from the concept of services, the concept of banking products, local and global competition between Islamic and conventional financial institutions, the evolution of banking systems in communication networks, technology methods and management Alomat (IT -IM) and the global trend to establish uniform standards for all services provided (the applicant - investor - shareholder - the owner Foundation - state) with the modernization of the quality departments, government, Risk, marketing, financial and Shari'a control.

\section{Islamic Banks}

The essence of Islamic banking is based on Islamic Shari'a. Islamic banks play an important role in the development of the economy by attracting and developing deposits, investing money by participating in the financing of economic and productive activities. Islamic banking does not revolve around money but seeks to finance real assets and that societies contribute to the development of their investments in achieving common public interest on the basis of sound and acceptable religion and legitimacy.

\subsection{Historical Stages of the Development of Islamic Banks}

In 1975, the first Islamic bankers were established, the Islamic Development Bank in Jeddah and the Dubai Islamic Bank in Dubai. Islamic banks were established in Bahrain, Malaysia, and other countries in the 1980s. (Meshaal., 2016)

\subsection{Definition}

It is a financial banking institution that aims at collecting and using money according to Islamic Shariya (law). The bank observes the Islamic law in all its banking and investment transactions. (banks Association in Jordan, 2015)

\subsection{Quality and Workmanship from an Islamic Perspective from the Holy Quran}

Abdullah Yusuf Ali translation: And say: Soon will Allah observe your work, and His messenger, and the believers: soon will be brought back to the knower of what is hidden and 


\section{Macrothink}

what is open: then will He show you the truth of all that you did." Al-Tawba, 105, Also, he translation: "We have indeed created man in the best of moulds." Al-Tin, 4. (Ali, 1938) (Quran, Al-Tawba, 105, Al-Tin, 4)

\subsection{Quality Standard of Islamic Banking Services (Islamic Commitment)}

The researcher has added the sixth dimension of an (Islamic commitment) to these dimensions being competent to Islamic banking and the nature of their work which must be achieved within the services for these Islamic banks directly. It focuses on assessing the level of commitment (Islamic Bank) of the procedures followed by the Shariah Supervisory Boards to have good faith in terms of adhering to the provisions and spirit of Islamic law, to study the extent of respect for the bank with the rules and principles of the law in achieving quality legitimate rules, instruments and financial products which complies with these legitimate rules.

\subsubsection{The Concept of Islamic Commitment}

It is the implementation of the activities and transactions of the institution in accordance with the provisions of Islamic law.

The concept of Shari'ah compliance includes two elements: the provisions of Islamic law as well as the activities and transactions of the institution. (Meshaal., 2016)

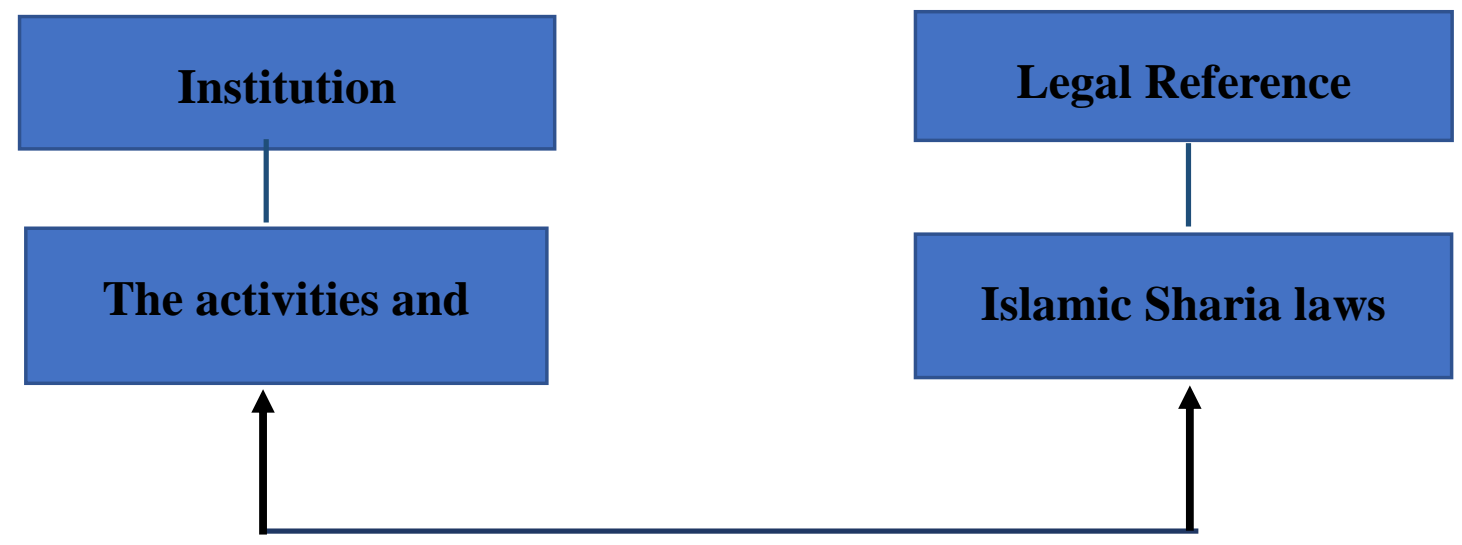

Figure 1. Islamic Commitment

\subsubsection{The Importance of Assessing the Islamic Commitment}

1) Shariah compliance is the reason for the existence of the Islamic financial industry (Islamic Financial Services Board Standard No. 10 "Guiding Principles for Regulating the Shariah Controls of Institutions Offering Islamic Financial Services", paragraph 1.)

2) It is an essential part of the operations of the Islamic financial institutions. The requirements of this obligation shall include all the activities of these institutions, their products and activities, and if they do not operate in accordance with Shari'a, any income 
generated by their operations shall not be regarded as a legitimate profit. (Islamic Financial Services Board Standard No. 1 "Guidelines for risk management of institutions (other than financial institutions) that are limited to the provision of Islamic financial services, paragraph 122). (Meshaal., 2016)

\subsection{Bank Classification and Objective}

The banking classification is a process whose purpose is to provide information and independent evaluation of both creditworthiness and good technical performance of banking, and the legal discipline of Islamic financial institutions, whether banks, funds, investment portfolios, takaful insurance companies or Islamic financial products that trade in markets such as Sukuk and so on.

The objective of the classification is to give the institution or product the correct quality so that the investors and those responsible for such classification will be able to achieve the qualitative level in terms of adherence to the Shari'a provisions related to services marketed under the slogan "Islamic" and the qualitative level of credit as well as solvency according to the approved standards in identifying risks. (Abu Ghada., 2004)

\subsubsection{Difference between Shari'a Classification and Credit Rating}

The credit rating differs from credit rating in that the latter is to assess the ability of financial institutions to meet their obligations to others and the strength of their solvency. The legal classification is not related to the solvency, financial strength of the institution, the credit quality of the financial paper nor the administrative efficiency, but rather to issue an independent opinion on the "legal quality".

Shari'a classification is a process whose purpose is to provide information and independent evaluation of the Shari'a discipline of Islamic financial institutions or those that offer Islamic banking or financial services. (Al-Qari, 2004)

\subsubsection{The Need for Legal Classification}

There is no doubt that the legitimate aspect is the most important in achieving the Islamic identity of Islamic financial institutions and products, while not forgetting the credit side, which is the subject of agreement in the banking industry in general because the preference shown by people towards Islamic financial institutions and on traditional products, but is an addition to legitimacy, and to take care of them to avoid the sacrament of haraam, It must therefore be measurable and there must be a way of judging those institutions and products based on their degree of commitment to this element, which is legitimate. It is inconceivable that all of them should be at the same level. If we do not find such a measure, the natural result is the deterioration of "legitimate quality" to the minimum, not the upper limit. (Abu Ghada., 2004)

The need for Shari'ah classification has emerged because Islamic banking is now in its golden age with unprecedented growth rates, increasing number of Islamic and Islamic financial institutions and Islamic financial services. Islamic financial products have become more complex and details are difficult to grasp in detail from these financial institutions. Which 
makes it necessary to find ways and means to enable the Muslim-client to verify the legal discipline, the need to have a measurable element has emerged and there must be a way to judge these institutions and products based on the degree of commitment to this element is legitimate. If we do not find such measurement, the natural result is the deterioration of the legal quality to the minimum and not the upper limit. (Al-Qari, 2004)

\subsubsection{Islamic Banks Need a Special Mechanism to Classify}

Islamic banks have become a necessity and have become a cornerstone of economic construction, not only for Islamic societies, but for the world at large, regardless of the evidence of international Islamic banking recognition and adoption by major financial institutions. Considering this quantitative expansion in the spatial area and in the diversity and professional coverage, it was necessary to complete the requirements of success and continuity to find a suitable mechanism for the philosophy and functions of Islamic banks to evaluate their performance and facilitate comparison between them in the performance.

Achieving inclusion in the classification requires combining the valuation of finance, investment, services and Shari'a compliance. Therefore, there are two main types to be considered in the classification of Islamic banks:

Type 1: The technical performance of the banking business in all its aspects in terms of meeting the requirements required to achieve the objectives of both the institution and its clients.

Type 2: Shari'a performance, in terms of ensuring compliance with the provisions and principles of Islamic Sharia, and the availability of qualities achieved for this purpose, both in the mechanisms of forensic control or procedures and stages of internal legal scrutiny.

The ruling on the institution in terms of "quality" legitimacy is only by the extent of its commitment and application of the decisions of its legitimacy and this is the focus of the classification of the legitimacy. (Abu Ghada., 2004)

Quality is a legitimate requirement

It was narrated that 'Aa'ishah (may Allah be pleased with her) said that the Prophet (peace and blessings of Allah be upon him) said:

"Allah is Blessed and exalted".

There are many directives in the effect that call for perfection of work and attention to quality began by calling for good character and good treatment and quality in everything, including the perfection of the Takfin dead and the quality of the memory of the sacrifice. (Al-Qari, 2004)

Quality is a legitimate requirement in every work done by man whether in his behaviour or in his public life or his business transactions and economic activity. Therefore, adopting quality standards, adopting high standards of performance and high levels of productivity, keenness to find excellent relations between the institution and its customers is a must and a demand that falls within the goal of perfection. Let him be the honourable year, but there is another 
aspect of the particularity of Islamic banks that we can call "legitimate quality". (Al-Qari, 2004)

Mashaal pointed out that "one of the prominent stations in the Islamic banking process is the emergence of institutions concerned with the classification of Islamic financial institutions and products. It demonstrates the awareness of the leaders and institutions that sponsor the Islamic banking business for the advanced stage reached by the Islamic financial industry and the need for rationalization, and legitimate commitment to the foundations of legal theory, practices and practical applications ». (Meshaal., 2016)

"The idea of rating Islamic financial institutions and products reflects their customers' interest in two aspects: Shari'ah compliance, requirements and financial solvency, as customers are now paying great attention to the most Shari'ah-compliant institutions and products, the most secure in terms of solvency and financial ability." Mashaal said that despite the importance of the credit rating and legitimacy of Islamic financial institutions and their customers alike, the Islamic financial institutions that provide the classification of institutions and products are still in the beginning of its work and did not win the public acceptance Which has been acquired by international credit rating agencies such as Moody's, Standard \& Poor's, Fitch and so on. According to Dr. Meshaal, existing Islamic rating institutions do not exceed three institutions. The Malaysian Classification Agency, which ranks Malaysian Islamic companies, and the International Islamic Classification Agency (ISIA), the oldest Islamic rating agencies (2006). It was founded by a number of Islamic banks, the credit rating institutions, led by the Islamic Development Bank, aim to serve the Islamic financial and banking sector by providing an independent evaluation of the activities and products of this sector to the benefit of investors from individuals and entities. The Islamic Classification Agency (ISNA) offers two types of ratings, namely: (Credit Rating), which aims at highlighting the strength and solvency of the Islamic Bank and its products. The second objective is to provide a legal classification to show the Islamic Bank's approval or products, and its commitment to the directives of its legitimate body. The third rating agency is the Shari'a Supervisory Board, which has not been more than two years old and has been approved by the General Assembly of the General Council of Islamic Banks (CIBAFI) in Jeddah. The Islamic financial products, as well as to ensure the safety of the practical application of products and their approval of the principles and provisions of Shariah, "Although the instructions of the Sharia'a Supervisory Board and the International Islamic Rating Agency are not binding on Islamic banks and financial institutions, the need today is very urgent to strengthen relations between the Islamic Financial Services Council and the central banks. An agreement between the Shari'a Supervisory Board and the International Islamic Classification Agency on the one hand and the executive heads of the formed banks of the General Assembly of the General Council on the other, to ensure that these banks give priority to the work of the directives of the two institutions in the most weighty classification standards, and to control the mechanisms of implementation, and to ensure institutional and administrative discipline at the enterprise and product level. "According to Dr. Meshaal, the legal classification of institutions and products is aimed at supporting their legal discipline, By setting grades for the level of this discipline, which will reflect the reality of the institutions, and give a clear 
indication of the customers about it ». (Meshaal., 2016)

According to the International Islamic Classification Agency (ISIA) on the quality of Shari'a classification, it does not aim at the quality of the Shari'ah classification, to indicate the Islamic ruling on Islamic financial products, and not to comment on the decisions of the Shari'ah Supervisory Boards in banks and financial institutions or to obtain the fatwas issued by them. The field of classification in assessing the level of commitment of banks and financial institutions - where the legal classification is limited to those institutions, banks and products that supervise their work (a Shariah body) - the procedures followed by the Shari'ah Supervisory Committees have a good structure In terms of adherence to the provisions and spirit of Islamic law, and to study a mechanism to assess the institution's compliance with the principles of Sharia and whether the Shari'a Supervisory Authority has sufficient authority to study and evaluate as well as the necessary information and the possibilities to carry out its tasks. However, this does not mean that the classification board and its subcommittees will not be interested in the decisions reached by the bodies and will not pay attention to what their experts may suggest. On the contrary, its evaluation will have an impact on the objective evaluation adopted by the agency, Classification by the International Islamic Classification Agency. (International Islamic Classification Agency, 2006).

The Council issued a Shari'a Quality rating (SQR AA) Agency Islamic International Rating Classification methodology for classifying degrees of quality legitimate ranking scale as follows: (International Islamic Classification Agency, 2006):

1. The Bank is committed to a very excellent level of standards and the requirements of the law in accordance with the methodology the legitimate quality classification approved by agency (AAA).

2. The Bank is committed to an excellent level of standards and the requirements of the law in accordance with the methodology the legitimate quality classification approved by agency (AA).

3. The bank is committed to a very high-level o of standards and the requirements of the law in accordance with the methodology the legitimate quality classification approved by $\operatorname{agency}(\mathrm{A})$.

4. The bank is committed to a high-level o of standards and the requirements of the law in accordance with the methodology the legitimate quality classification approved by agency (BBB).

5. The bank is committed to a satisfaction level o of standards and the requirements of the law in accordance with the methodology the legitimate quality classification approved by agency (BB).

6. The bank is committed to acceptable level o of standards and the requirements of the law in accordance with the methodology the legitimate quality classification approved by agency (B). 


\section{Discussion}

Shari'ah bodies and their regulatory role are a legitimate and legal necessity for the Islamic financial industry.

The Fatwa and Shari'a Supervisory Board is particularly important in the structure of the Islamic financial institution, since its motto cannot have a balance of truth and reality except with the commitment of that institution to the principles and rules of Islamic law and its proper application.

Moreover, the establishment of Shariah bodies for Islamic financial institutions is a legal issue. Most Islamic banks and other Islamic financial institutions stipulate in their internal regulations and regulations that their transactions are in accordance with the provisions of Islamic Sharia. And declare and ratify the operations of the Foundation. The existence of the Shari'ah board and the performance of its duties in any financial institution, even if it does not raise the Islamic logo, is a source of reassurance to the institution's commitment to the provisions of Islamic law, and this is what makes the fundamental difference between them and the traditional financial institution.

\section{Conclusion and Result}

In countries where many Muslim citizens do not wish to deal with commercial banks in a religious way, Islamic banks have a set of measures to improve the quality of their services in order to be a strong competitor to other commercial banks. And diversify those services to suit the wishes and aspirations of its customers by understanding the trends and expectations of customers towards the services provided by Islamic banks. This study will help the Islamic banking departments to know the quality standards of the banking services of Islamic banks by adding a new standard that represents the religious commitment in other words, the extent to which religious teachings are implemented in their correct form and not in form, as we see in some Islamic banks now. Islamic banking services to be applied in all future studies and not similar studies with commercial banks. We reach in this research that the author added a new dimension for the traditional Standard Quality Banking Services as Islamic commitment which is specified for Islamic banks around the world to give high perception about the quality services for those banks.

\section{References}

Abu, G. A. (2004). Islamic Banks Classification and Total Quality Standards. Fourth Conference of the Shari'ah Councils. Manama: Accounting and Auditing Organization for Islamic Financial Institutions.

Al musaed, K. (1999). Marketing services and applications. Amman: Dar Manahej Publisher and distribution.

Al-Azzawi, M. (2001). Total Quality in Higher Education. First Symposium: Total Quality Managemen. National Committee for Total Quality.

Al-Damour, H. (2002). Services Marketing. Amman: Dar Wael for printing and publishing. 
Ali, A. (1938). The Holy Qur'an: Text, Translation, and Commentary. Birmingham: Islamic propagation center.

Al-Qari, M. (2004). Classification of Islamic Banks and Total Quality Standards. Jeddah: King Abdulaziz University.

Al-Taleb, S. (2003). Measure the quality of Islamic banking services in the Hashemite Kingdom of Jordan: Analytical study field. Journal of Jerash University, 2(3), 12-34.

Cronin, J., \& Taylor, S. (1992). Measuring service quality: a re-examination and extension. Journal of Marketing, 56, 55-68. https://doi.org/10.2307/1252296

Darwish, M. (2016). Analysis of the quality of Islamic banking services an applied study on Islamic banks in Palestine. Al Quds Open University.

Ennew, C., Reed, G., \& Binks, M. (1993). Importance-performance analysis and the measurement of service quality. European Journal of Marketing, 27(2), 59-70. https://doi.org/10.1108/03090569310026402

Gronroos, C. (1995). Services Management and Marketing. Lexington: Lexington Book.

Grönroos, C. (2000). Service Management and Marketing: a customer Relationship Management Approach. England: John Wiley \& Sons, ltd.

Haddad, A. (1999). Marketing of banking services. Cairo: Al-Bayan for printing, publishing and distribution.

Howcroft, J. (1991). Customer satisfaction in retail banking. service industry journal, 11-17. https://doi.org/10.1080/02642069100000002

Imam, W. (2003). Determinants of the quality of health service and the impact on the satisfaction of clients in the university and private hospitals in Al-Duqhalya Governorate. The Egyptian Journal of Commercial Studi, 27(4).

Kotler., P. (1975). Marketing Management, Analysis, Planning and Control, Englow Wood Cliff. New jersey: Prentice Hill.

Meshaal., A. (2016). How to Evaluate the Evolution of Shari'ah commitment in the Islamic Financial Industry in 40 Years. AAOIFI world conference. Manama: AAOIFI world conference.

Mohammad, F. (2014). Islamic Banking Quality Standards. Retrieved from Al Sharq Electronic Magazine,: https://www.al-sharq.com/

Primio, D. (1997). Quality Assurance in Services Organization. London: Chilton Book Co.

Quran, T. H. (Al-Tawba, 105, Al-Tin, 4). The Holy Quran. Madinah Munawwarah: King Fahd Complex for Printing the Holy Quran.

Taylor, S., \& Baker, T. (1994). An assessment of the relationship between service quality and customer satisfaction in the formation of consumers purchase intentions. Journal of retailing, 


\section{Macrothink}

70. https://doi.org/10.1016/0022-4359(94)90013-2

Zeithaml, A., Berry, L., \& Parasuraman, A. (1996). The behavioural consequences of service quality. Journal of Marketing, 60, April, 31-46. https://doi.org/10.2307/1251929

Zeithaml, A., Parasuraman, A., \& Malhotra, A. (2000). A Conceptual Framework for Understanding E-Service Quality: Implications for Future Research and Managerial Practice. Working paper, Report Number 00-115.: Marketing Science Institut.

\section{Copyright Disclaimer}

Copyright for this article is retained by the author(s), with first publication rights granted to the journal.

This is an open-access article distributed under the terms and conditions of the Creative Commons Attribution license (http://creativecommons.org/licenses/by/4.0/). 